\title{
Visi Profetis Kehidupan Sosial Umat Kristen dalam Demokrasi Menurut John W. De Gruchy
}

\author{
Aseng Yulias Samongilailai \\ Sekolah Kristen Ketapang 1, Indonesia \\ asengsamongilailai29@gmail.com
}

\begin{tabular}{l} 
Article History \\
Received: \\
02 November 2019 \\
Revised: \\
25 November 2019 \\
Published: \\
November 2019 \\
\hline Keywords \\
(Kata kunci): \\
democracy; \\
prophetic vision; \\
Christian social life; \\
John W. De Gruchy; \\
kehidupan sosial \\
Kristen; \\
visi profetis \\
\\
\\
D0I: \\
http://dx.doi.org/10. \\
33991/epigraphe.v3i2.128
\end{tabular}

\section{Abstract}

This article reviews how church members - Christians - should play a role in social life, especially in the context of Indonesia's democratic life. The role of church members is derived from a theoretical study of John W. De Gruchy's thoughts on the prophetic vision which also functions as the basis for this role. The prophetic vision on which the role is based covers the importance of upholding justice, presenting the love of Jesus and the kingdom of God, and of how the Christian community should become an ecclesia that has a positive, constructive impact on social situations that are experiencing degradation in various lines of life.

\begin{abstract}
Abstrak
Artikel ini mengulas tentang bagaimana mestinya warga gereja - umat Kristen - ikut berperan dalam kehidupan sosial khususnya dalam konteks kehidupan demokrasi Indonesia. Peran warga gereja yang diperoleh berasal dari kajian teoritis terhadap pemikiran John W. De Gruchy tentang visi profetis yang sekaligus berfungsi sebagai dasar/landasan dari peran tersebut. Visi profetis yang menjadi landasan peran meliputi tentang pentingnya menegakkan keadilan, menghadirkan kasih Yesus dan kerajaan Allah, dan tentang bagaimana harusnya komunitas Kristen menjadi ecclesiā yang memiliki dampak positif, konstruktif dalam situasi sosial yang sedang mengalami degradasi dalam berbagai lini kehidupan.
\end{abstract}

\section{Pendahuluan}

Demokrasi jelas bukan istilah baru dalam perbendaharan kata dan istilah kita sebagai warga negara Indonesia karena kita terlahir dan hidup dalam prinsip atau model pemerintahan tersebut. Berbagai rentetan peristiwa, fenomena, dan tragedi telah mewarnai perjalanan penggunaan dan penerapan model sistem pemerintahan tersebut di Indonesia. Namun sekalipun demikian, model tersebut masih dipertahankan karena diyakini merupakan sistem pemerintahan yang ideal, mampu mengatasi keanekaragaman suku, adat, ras dan agama yang merupakan ciri khas Indonesia. ${ }^{1}$ Dengan model tersebut pula, sejatinya Indonesia diharapkan dapat menjadi rumah bersama yang aman,

\footnotetext{
${ }^{1}$ Victor Silaen, Bertahan di Bumi Pancasila: Belajar dari Kasus GKI Yasmin (Jakarta: YKBK, 2012); Andreas A. Yewangoe, Tidak Ada Penumpang Gelap (Jakarta: BPK Gunung Mulia, 2015); Andar Ismail, Selamat Mengindonesia: 33 Renungan tentang Kebinekaan (Jakarta: BPK Gunung Mulia, 2019).
} 
nyaman, ramah- tamah, dan menjunjung tinggi hak, harkat dan martabat rakyat tanpa adanya diskriminasi terhadap suatu kelompok, golongan, ras, agama, dan budaya yang biasnya dapat merobek persatuan dan kesatuan bangsa yang selama ini telah diperjuangkan dan sementara terus dipelihara.

Heru Nugroho dalam tulisannya Demokrasi dan Demokratisasi: Sebuah Kerangka Konseptual untuk Memahami Dinamika Sosial-Politik di Indonesia menjelaskan beberapa hal penting, yakni: 1) bahwa pada dua dasawarsa terakhir, khususnya di banyak negara berkembang, istilah demokrasi menjadi kian populer baik dalam tingkat wacana maupun dalam ranah gerakan sosial politik. ${ }^{2}$ Banyak negara tersebut menganggap demokrasi mampu mengatur dan menyelesaikan hubungan sosial politik, baik dalam kepentingan antar individu dalam masyarakat, hubungan antar masyarakat, masyarakat dan negara maupun antar negara di dunia; ${ }^{3}$ 2) bahwa dalam demokrasi tampak warga negara mendapatkan haknya, yakni kesempatan dan kemampuan untuk menentukan pilihan akan pemimpin politiknya tanpa dipolitisasi oleh pihak manapun; 3) bahwa dalam demokrasi, nilai moral dan etika/kesantunan yang ada tidak hanya sekadar ada dalam wacana dan piagam undang-undang, namun mesti ada dan memiliki impact. Hal ini penting agar praktik-praktik si kuat menindas si lemah tidak terjadi dan terulang kembali, karena jika demikian demokrasi akan tampak sebagai sebuah konsep/model yang dilematis; 4) bahwa konsep liberalisasi yang melekat erat dan merupakan "roh demokrasi" mestilah dimaknai sebagai sebuah masyarakat yang memiliki aturan (golden role, dalam hal ini UUD 1945 dan Pancasila), yang diperuntukkan menjamin pemberian ruang gerak dan kesempatan yang sama setara bagi warga negara untuk melakukan aktifitas kehidupannya.

Golden role tersebut mestilah dihormati dengan sadar oleh setiap/semua aktorpelaku sosial dalam segala tingkat dan kapasitas, artinya meliputi penguasa, pemerintah, pengusaha dan rakyat. Penyimpangan dan penyelewengan terhadap golden role tersebut tentu saja dapat ditindak tegas menurut dan melalui lembaga peradilan tanpa pandang bulu. Lebih jauh, apabila dalam praksis politik, terkhusus "penunjang kekuasaan" melakukan pelanggaran maka konsep liberalisasi yang telah diusulkan pemaknaannya akan jatuh dan tereduksi dalam paham Darwinisme. Paham Darwinisme mengajarkan bahwa konsep liberalisasi adalah kebebasan yang tanpa batas, di mana semua orang memiliki kebebasan mutlak - namun mis-akhlak dan tanggung jawab untuk berbuat semaunya, bahkan dalam ranah politik, partai politik memiliki kebebasan yang seluas-luasnya untuk berorasi sekalipun dengan demagogi, spesifikasi paham Darwinisme adalah barangsiapa yang kuat maka dialah yang berkuasa. Dengan paham ini, niscaya akan dicapai equilibrium sosial, sementara justru chaos mendominasi cakrawala demokrasi.

\footnotetext{
${ }^{2}$ Heru Nugroho, "Demokrasi dan Demokratisasi: Sebuah Kerangka Konseptual Untuk Memahami Dinamika Sosial-Politik di Indonesia,” Jurnal Pemikiran Sosiologi, Volume 1/1 (2012): 2. ${ }^{3}$ Ibid.
} 
Merespons tulisan Nugroho, penulis ingin mendialogkannya dengan salah satu kasus yang masih segar dalam ingatan, yakni kasus penistaan agama oleh Mantan Gubernur DKI Jakarta, Basuki Tjahaja Purnama - Ahok/BTP. Isu surah Al-Maidah 51 yang dihadapi oleh Ahok dapat membantu pembaca untuk mengukur praktik demokrasi publik Indonesia. Secara akal sehat tentu kita dapat memisahkan mana yang faktual dan mana yang imajiner dalam isu yang seharusnya tidak perlu menyedot perhatian dan aksi demostrasi-destruktif yang sampai beberapa kali bahkan masih bertahan menjadi sebuah gerakan dengan wajah "alumni". Akal jernih kita dapat menangkap dengan cepat bahwa yang dikritik oleh Ahok dalam pidatonya ketika kunjungan kerja di Kepulauan Seribu 27 September 2016 yang lalu bukanlah surat Al-Maidah, juga bukan Islam, dan bahkan juga bukan para pendengarnya saat itu. Yang dikritik olehnya adalah instrumentalitas agama, termasuk ayat-ayat kitab suci, untuk melayani politik. ${ }^{4}$ Dari kasus tersebut tampak bahwa ada sisi lain dalam demokrasi Indonesia yang sifatnya krusial, yakni masih bercokolnya sentimentalitas primordialisme. Hal ini dapat saja dilihat sebagai salah satu kewajaran mengingat bahwa Indonesia merupakan salah satu negara multikultur dan sosiokultur di dunia (Kusumohamidjojo, 2000, p. 45) ${ }^{5}$, namun di sisi lain kasus tersebut jelas bertentangan dengan idealisme demokrasi seperti yang telah dipaparkan oleh Nugroho dalam tulisannya.

Dalam hal ini, penulis menilai bahwa tidak cukup hanya menekankan aspek kesadaran dari semua aktor/pelaku sosial maupun masyarakat. Karena perlu disadari bahwa hampir setiap individu memiliki kecenderungan terhisab dalam suatu komunitas, sehingga ketika berjumpa dengan individu yang lain dalam ranah apa pun, sebenarnya ia sedang berjumpa pula dengan individu yang juga terhisab dalam suatu komunitas yang lain seperti dirinya. Singkatnya, ketika terhisab, loyalitas acap kali menutup rasionalitas. Penulis melihat bahwa perlu pula menambahkan aspek lain di samping peran sadar semua pelaku/aktor dan masyarakat. Argumen dan penjelasan F. Budi Hardiman dalam Demokrasi dan Sentimentalitas: Dari "Bangsa Setan-setan, Radikalisme Agama, sampai Post-Sekularisme akan menolong pembaca, ia menjelaskan, demokrasi adalah rasionalisasi dan demokratisasi adalah proses rasionalisasi. Hasil dari rasionalisasi salah satunya adalah keberhasilan suatu komunitas/masyarakat untuk melampaui loyalitas-loyalitas primordial di dalamnya, seperti agama dan etnisitas yang tidak diperlakukan seolah entitas gaib yang tabu untuk dibicarakan, namun justru menjadi bagian dari komunikasi konstruktif publik dan dikontrol oleh penalaran publik. ${ }^{6}$

Dua perspektif di atas, Nugroho dengan gagasan persuasif kepada semua aktor sosial supaya berperan secara sadar dan pro aktif untuk menghormati golden role sebagai tata tertib kehidupan bersama dan Hardiman dengan rasionalitas publik yang

\footnotetext{
${ }^{4}$ Sabar Subekti, "Gereja di Tengah Maraknya Politik Identitas dan Fundamentalisme di Indonesia," Jurnal Lensa 5/1 (2013): 23-33.

${ }^{5}$ B. Kusumohamidjojo, Kebhinekaan Masyarakat Indonesia: Suatu Problematik Filsafat Kebudayan (Jakarta: Grasindo, 2000), 45.

${ }^{6}$ F. Budi Hardiman, Demokrasi dan Sentimentalitas: Dari “Bangsa Setan-setan, Radikalisme Agama, sampai Post-Sekularisme (Yogyakarta: Kanisius, 2018), 71-73.
} 
melampaui loyalitas-loyalitas primordial komunitas dan golongan, dapat merupakan idealisme dan optimisme terhadap para pemeran pentas kehidupan sosial di dalam hidup berdemokrasi. Pula, dua perspektif di atas sedikitnya menjadi landasan pemikiran dan rumusan penulisan tulisan ini. Dalam hal ini penulis menaruh perhatian khusus kepada bagaimana peran warga negara yang secara kalkulasi pemeluk agama tergolong sebagai salah satu "minoritas" di negeri ini, yakni Kristen. Dengan demikian, yang menjadi rumusan masalah dalam tulisan ini adalah bagaimana warga gereja yang sekaligus warga negara bisa ikut berpartisipasi aktif dalam kehidupan sosial khususnya dalam kehidupan berdemokrasi seperti yang diharapkan oleh Nugroho dan Hardiman, mengingat Indonesia terdiri dari masyarakat yang sangat majemuk. Sebagaimana judul tulisan ini, maka tentu tulisan ini merupakan kajian pada teori John W. De Gruchy.

\section{Metode}

Tulisan ini menggunakan metode penelitian deskriptif analitik yang merupakan suatu metode yang berfungsi untuk mendeskripsikan atau memberikan gambaran terhadap objek yang diteliti melalui data atau sampel yang telah terkumpul sebagaimana adanya. Sebagaimana telah disinggung dalam rumusan masalah, maka objek yang akan diteliti adalah teori John W. De Gruchy demi menemukan bagaimana seharusnya orangorang Kristen berperan dan bersikap secara aktif, konstruktif, dan positif dalam lingkungan demokrasi. Namun sebelumnya, penting untuk diketahui bahwa berbicara mengenai bagaimana peran yang diharapkan dari warga gereja, maka hal itu berbicara mengenai apa dasar dari peran yang diharapkan tersebut sebagaimana tersirat dalam judul artikel ini. Adapun outline penulisan dalam artikel ini meliputi; 1) pemaparan tentang pemikiran John W. De Gruchy sebagai dasar atau landasan dari peran diharapkan dari warga gereja dan 2) pemaparan implementasi pemikiran John W. De Gruchy sebagai peran warga gereja yang diharapkan bagi praksis kehidupan. Data primer yang akan penulis gunakan adalah buku karya Gruchy yang berjudul Christianity and Democracy. Sedangkan data sekunder terdiri dari beberapa pemikiran para ahli sebagai bahan perbandingan dengan pemikiran John W.De Gruchy.

\section{Pembahasan}

\section{Kekristenan dan Demokrasi}

Gruchy menegaskan bahwa pada dasarnya hubungan antara kekristenan dan demokrasi bersifat ambigu, terkhusus ketika menoleh kepada rekam jejak sejarah dari masing-masing. Kecenderungan ambiguitas yang tentu saja heterogen tersebut tampak dalam gerakan kekristenan yang sifat dan coraknya konservatif, reformis, dan radikal. Sedangkan demokrasi, tampak dalam evolusinya yang liberalis dan sosialis. Penting untuk digarisbawahi bahwa dalam hal ini orang-orang Kristen sama sekali tidak menganggap demokrasi (sistemnya) sebagai bentuk pemerintahan yang "terbaik". Walaupun gereja-gereja bebas Protestan tertentu terkait erat dengan kemunculan 
demokrasi liberal, namun kekristenan mainstream secara keseluruhan, khususnya Katolisisme Roma, sejak semula menolaknya (Gruchy, 1995, p. 8). ${ }^{7}$

Hal itu dikarenakan, khususnya sejak masa Pencerahan sewaktu demokrasi menjadi sama dengan liberalisme ${ }^{8}$, yang kemudian membuat demokrasi dianggap sebagai buah karya revolusi dan dipandang selaku serangan gencar atas iman dan nilainilai kristiani tradisional. Stanley Hauerwas menegaskan bahwa "gereja ada bukan untuk memberi etos bagi demokrasi atau segala bentuk lain organisasi sosial". ${ }^{9}$ Gruchy mengutip Adrian Hastings yang mengatakan bahwa pada dasarnya, kekristenan/agama Kristen tidak memiliki model politik yang ideal yang tercantum dalam piagam dasarnya dan pada saat yang sama, kekristenan/agama Kristen tidak dapat disamakan dengan model/sistem pemerintahan apapun. ${ }^{10}$ Menyamakan agama Kristen dengan sebuah sistem politik tertentu jelas merupakan sebuah kesalahan, namun juga tidaklah berarti bahwa semua sistem pemerintahan sama-sama dapat diterima bagi iman Kristen.

\section{Visi Profetis Menurut John W. De Gruchy}

\section{Biarlah Keadilan bergulung-gulung seperti Air}

Para nabi, dalam seruan nubuatan, peringatan, dan kecaman sekalipun kepada orang-orang Israel, selalu didasarkan pada dua hal, yakni: 1) Yahweh adalah Allah yang telah membebaskan mereka dari perbudakan di Mesir, dan 2) Yahweh telah mengikat perjanjian dengan mereka di Sinai, bahwa Yahweh adalah Allah mereka dan mereka adalah umat pilihan dan kepunyaan-Nya. Dua hal di atas merupakan landasan dan fondasi bagi semua sisi dan segi kehidupan orang-orang Israel, tentang bagaimana mereka hidup sebagai umat yang telah dibebaskan dan dimerdekakan, dan tentang bagaimana mereka berbakti kepada Allah mereka, Yahweh. Oleh Gruchy, 2 landasan di atas digunakan untuk menjelaskan sasaran kritik para nabi atas kehidupan orang-orang Israel yang pasang-surut dalam hubungan vertikal dan horizontal. ${ }^{11}$

Pertama, Gruchy ${ }^{12}$ melihat bahwa pada periode pertama/awal permukiman orangorang Israel di Kanaan, pergumulan kenabian yang sangat urgen kala itu adalah perjuangan untuk melawan "Baalisme". Pergumulan tersebut menjelaskan bahwa ternyata telah terjadi penyimpangan kesetiaan, dari Yahweh kepada Baal dengan modus ingin membangun relasi atau tatanan sosial. Browning menjelaskan bahwa Baal adalah dewa kesuburan dan pertanian. Ketika Israel baru menetap di tanah Kanaan, mereka tergiur dengan godaan untuk beralih kepada Baal. Intinya, pertentangan antara Yahweh

8.

${ }^{7}$ John W. De Gruchy, Christianity and Democracy (Cambridge: Cambridge University Press, 1995),

${ }^{8}$ Nugroho, "Demokrasi dan Demokratisasi", 5-6.

${ }^{9}$ Stanley Hauerwas, A Community of Character: Toward a Constructive Christian Social Ethic

(Notre Dame, Indiana: University of Notre Dame Press), 12.

${ }^{10}$ Grucy, Christianity and Democracy, 8-9.

${ }^{11}$ Ibid., 40-41.

${ }^{12}$ Ibid., 41. 
dan Baal dalam kehidupan orang-orang Israel adalah tentang kesetiaan mereka. ${ }^{13}$ Merespons hal tersebut, para nabi menolak dan bahkan menentang keras legitimasi suatu tatanan sosial yang merusak ketaatan kepada Yahweh, yang menindas kaum tani, dan yang menghancurkan dasar keberadaan orang-orang Israel. Tidak heran banyak upaya dan usaha dilakukan oleh para nabi demi melakukan semacam "reformasi" kultus demi memperbaiki kehidupan sosial dan keagamaan Israel, seperti yang tertulis dalam 2 Raj. 11:18 di mana kuil Baal dihancurkan dan 1 Raj. 18:20-40 di mana para pengikut Baal dikalahkan secara total. Pembersihan tersebut berlanjut kembali dalam reformasi Yosia dalam cerita 2 Raj. 23:4-5.

Kedua, Gruchy melihat bahwa reformasi Deuteronomis tidak hanya berpusat pada permasalahan keagamaan semata, melainkan juga permasalahan ekonomi. ${ }^{14}$ Ketika Israel telah menjadi suatu monarki pemerintahan, cita-cita sosial egaliter para nabi terus-menerus mendapatkan ancaman dan tekanan, tidak terkecuali melalui pajak yang memberatkan dan penyitaan tanah sebagai ganti pembayaran utang-piutang. Kondisi tersebut melahirkan reformasi Deuteronomis yang menyerukan Israel untuk meneladani/meniru kepedulian Yahweh terhadap orang miskin, tertindas, janda, yatim piatu, dan korban masyarakat lainnya. Bahkan orang asing pun harus diperlakukan secara adil dan tetap menaruh respek terhadap hak-hak mereka. Selain itu, para nabi juga menyerukan agar administrasi hukum yang berkenaan dengan masalah pribadi antarpribadi dalam jumlah yang besar harus dilakukan dalam hal ranah kewajiban perjanjian untuk mencari dan menemukan kebenaran Allah, yakni Yahweh's burning compassion for the oppressed. Tsedākah, kebenaran sosial atau keadilan, merupakan barometer "kesehatan masyarakat". Hal ini berarti bahwa ketidakadilan sosial harus secara teratur diperbaiki sebagaimana diisyarat dan ditentukan dalam ajaran Tahun Yobel (Ima. 7). Tidak kalah penting, bahwa kekuatan "orang-orang istimewa" haruslah berada di bawah pengawasan dan kendali demi memastikan bahwa mereka juga diperhitungkan dan dilibatkan untuk tunduk kepada administrasi dan hukum demi kebenaran sosial dan terciptanya masyarakat yang adil.

Dalam bagian ini Gruchy menegaskan bahwa ekspresi terbaik untuk mengekspresikan visi kenabian adalah shalom. ${ }^{15}$ Shalom mengacu pada penyembuhan, pemulihan, dan keutuhan hubungan manusia, kesejahteraan ciptaan, dan hubungan perjanjian antara Yahweh dan Israel. Shalom juga merupakan sinonim untuk mengekspresikan keselamatan dan juga mengandung dimensi eskatologis, guna menunjukkan bahwa apa yang akan dilakukan dan dikerjakan oleh Allah akan melampaui apa yang ada sekarang. Tetapi shalom juga tidak dapat dipisahkan dari tindakan dan praktik keadilan, semisal nabi-nabi palsu. Mereka menyatakan shalom tanpa keadilan (Yer. 14:13), padahal shalom adalah karunia Allah bagi mereka yang

\footnotetext{
${ }^{13}$ W.R.F. Browning, Kamus Alkitab: Panduan Dasar ke dalam Kitab-kitab, Tema, Tempat, Tokoh, dan Istilah Alkitabiah (Jakarta: BPK Gunung Mulia, 2014), 41.

${ }^{14}$ Grucy, Christianity and Democracy, 42-44.

${ }^{15}$ Ibid., 44-45.
} 
melakukan keadilan. Gruchy menegaskan bahwa visi kenabian "biarlah keadilan bergulung-gulung seperti air" merupakan pernyataan persuasif untuk perjuangan kebebasan, kesetaraan politik, dan keadilan sosial.

\section{Yesus dan Kerajaan Allah}

Ernst Troeltsch sebagaimana dikutip oleh Gruchy mengamati bahwa Yesus mempersembahkan diri-Nya demi kepentingan kaum tertindas, menganggap kekayaan sebagai bahaya bagi jiwa dan terlebih melawan aristokrasi imam Yahudi yang mewakili kekuatan-kekuatan agamawi yang dominan pada masanya, hal ini jelas dalam Injil Sinoptik dan Kanonik. ${ }^{16}$

Yesus merupakan seorang Yahudi, itu artinya Ia akrab dan mengetahui dengan baik bagaimana bingkai atau pola pikir orang Yahudi masa. ${ }^{17}$ Selain itu, Yesus juga lekat dengan tradisi kenabian, baik sebagai orang yang menyatakan kebaikan Allah dalam menghadapi ketidakadilan pada masa-Nya maupun sebagai orang yang secara aktif berupaya melakukan pembaruan sosial atas dasar "Kerajaan Allah". Kerajaan Allah merupakan konsep yang sangat penting dan merupakan pusat atau inti dari pemberitaan Yesus yang tercatat dalam keseluruhan kitab-kitab Injil Kanonik. Hal tersebut juga diungkapkan oleh I. Howard Marshal yang pendapatnya dikutip oleh Craig L. Blomberg bahwa Kerajaan Allah merupakan tema sentral pengajaran Yesus. ${ }^{18}$ Dalam Injil Lukas 4:18-19 yang berbunyi: "Pneûma kyríou ep' emè hoû heíneken échrisén me euangelísasthai ptōchoîs, apéstalkén me,kērýxaiaichmalótois áphesin kaì typhloîs anáblepsin, aposteîlai tethrausménous en aphései, kērýxai eniautòn kyríou dektón". Kalimat di atas menggambarkan Yesus sebagai tokoh yang memandang misi-Nya sejak semula sesuai dengan firman dari seorang nabi pasca-pembuangan, sebagai kabar baik bagi kaum miskin, pembebasan bagi para tawanan, penglihatan bagi orang buta, kebebasan bagi korban-korban masyarakat, serta penyambutan Tahun Yobel, yang di dalamnya pembaruan masyarakat dan lingkungan hidup secara keseluruhan dapat berlangsung (Yes. 61:1-2). ${ }^{19}$

Beberapa aspek terkait yang perlu disebutkan guna memperlihatkan pentingnya politik Yesus sebagai seorang nabi. Aspek yang pertama adalah cara-Nya menjungkirbalikkan relasi sosial dan berusaha membangun kembali relasi sosial itu menurut garis egaliter. Yesus mendemonstrasikan hal ini dalam relasi-relasi-Nya sendiri yang bersifat antarpribadi dan menerapkannya dalam membangun komunitas para murid-Nya. Yesus juga tidak menghiraukan sekat (batasan) sosial dan sekat hierarkis yang bersifat gender atau kelas, kesucian atau kesalehan ritual yang secara tradisional memisahkan umat satu sama lain. Rudolf Bultmann sebagaimana dikutip oleh Bammel

\footnotetext{
${ }^{16}$ Grucy, Christianity and Democracy, 46; John H. Yoder, The Politics of Jesus (Grand Rapids: Eerdmans, 1972), 3.

${ }^{17}$ Ernst Bammel dan C.F.D Moule (ed), Jesus and The Politics of His Day (Cambridge: Cambridge University Press, 1984), 129. 296.

${ }^{18}$ Craig L. Blomberg, Interpreting The Parables (Downers Grove (Illinois: InterVarsity Press, 1990),

${ }^{19}$ Grucy, Christianity and Democracy, 46-47.
} 
mengatakan bahwa Yesus melawan kekerasan dalam hukum pemurnian, polemik melawan legalisme Yahudi, dan prostitusi. ${ }^{20}$ Lebih jauh, Yesus menentang pola-pola kepemimpinan otoriter dan patriarkal dalam Yudaisme dan kebudayaan-kebudayaan di sekitarnya saat itu. $^{21}$

Aspek yang kedua, sebagaimana tampak dalam pengusiran yang dilakukan-Nya atas kuasa setan dan pelayanan penyembuhan-Nya, Yesus peduli akan keutuhan umat secara orang per orang dan karena itu peduli pula akan kebebasan mereka dari bermacam bentuk kungkungan yang merusak kualitas kehidupan yang dikehendaki Allah. Di sini jelas bahwa Yesus memang membebaskan umat dari kungkungan kuasakuasa yang merendahkan martabat manusia, dan memungkinkan mereka menemukan martabat anugerah Allah seperti Ia juga memberdayakan mereka untuk menghayati kehidupan secara lebih bertanggung jawab bagi sesama. Pengusiran setan yang dilakukan Yesus dan mukjizat-mukjizat penyembuhan-Nya merupakan tindakan simbolis yang kuat, yang memberi kesaksian atas pemerintahan Allah. Bukan karena tindakantindakan itu menentang hukum alam, melainkan karena menentang struktur-struktur keberadaan sosial yang terdalam. ${ }^{22}$

Aspek yang ketiga, Yesus dengan gigih menentang ketidakadilan sosial dan ekonomi. Hal ini tampak dalam berbagai cara, tidak hanya pada ajaran-Nya tentang kekayaan dan kemiskinan. Ajaran Yesus semacam itu bertahan selama beradab-abad setelah gereja menyadari sulitnya menyetujui riba atau bahkan pemilikan kekayaan pribadi tanpa syarat dan kualifikasi yang ketat. ${ }^{23}$ Kalimat Yesus dalam Matius 6:33: "zêteîte dè prō $\square$ ton tè̀n basileían [tô̂ theô̂] kaì tè̀n dikaiosýnēn autôu, kaì taûta pánta prostethế setai hymîn". Kalimat atau nasihat Yesus ini merupakan tantangan kenabian yang jelas untuk mengupayakan keadilan, khususnya demi kaum miskin, sebagai landasan kehidupan sosial. Dalam menjalankan misi-Nya untuk memproklamasikan kedatangan Kerajaan Allah, Yesus menghadapi otoritas agamawi dan politis pada masa-Nya yakni mereka yang mengontrol pendapatan bait suci di Yerusalem. Ini membawa-Nya ke penyaliban - kematian yang disebabkan oleh kepentingan agamawi, intrik-intrik politik dan tuntutan massa.

Melalui pandangan Reinhold Niebuhr yang dikutip oleh Gruchy (1995) mengatakan bahwa banyak orang telah mengakui kemungkinan yang tidak mungkin (utopis) dari amanat kenabian Yesus yang radikal dan karenanya memandangnya sebagai interim ethics. Yoder juga menjelaskan hal itu bahwa memang ada pandangan yang mengatakan bahwa pengajaran Yesus soal etika tidak relevan. Alasannya adalah pengajaran etika Yesus terlampau singkat sehingga dianggap interim (sementara).

\footnotetext{
${ }^{20}$ Bammel dan Moule, Jesus and The Politics of His Day, 130.

${ }^{21}$ Grucy, Christianity and Democracy, 47.

${ }^{22} \mathrm{Ibid}$

${ }^{23}$ Ibid., 48.
} 
Selain itu Yesus adalah seorang yang dipandang sebagai figur sederhana dari daerah pedesaan. $^{24}$

Tetapi ada yang tidak bisa dipungkiri bahwa kesaksian profetis Yesus - Kerajaan Allah - memberikan kritik radikal terus-menerus terhadap semua sistem politik yang merendahkan martabat manusia lewat dominasi yang tidak adil atas orang lain. Selain kritik, Kerajaan Allah juga berbicara mengenai pembaharuan bagi orang-orang miskin dan teraniya, yakni mereka bisa dan berhak untuk berinteraksi bersama, bekerjasama, dan mereka juga disembuhkan secara pribadi. ${ }^{25}$ Dalam ketaatan kepada Yesus, selalu ada orang yang berupaya memelihara kesaksian ini dalam masyarakat, dan kerap kali dengan pengorbanan yang besar. Mereka yang melakukannya menjadi alat dalam menentang tirani serta memberikan kritik radikal terhadap semua sistem sosial yang tidak adil. $^{26}$

\section{Ekklēsia Kristen}

Dalam kesinambungan dengan Yesus, orang Kristen mula-mula yang berupaya mewujudkan suatu bentuk komunitas yang egaliter dalam kelompok mereka sendiri yakin bahwa kematian dan kebangkitan Yesus telah mengakhiri tatanan kehidupan lama yang mengandung pemilahan manusia, dosa, dan kebencian. Bagi Niebuhr ${ }^{27}$ egaliter diartikan sebagai egaliter justice yang mana untuk melawan semua orang yang memiliki hak istimewa karena memiliki kekayaan.

Dalam konteks di atas, baptisan menjadi sesuatu yang penting. Baptisan menjadi sebuah tanda masuk ke dalam kelompok mesianis yang merupakan representasi kasat mata dari kemanusiaan baru milik Allah, dan dengan demikian baptisan juga berarti sebagai penolakan radikal terhadap semua perbedaan sosial yang memecah belah. Malina menegaskan "baptism is the dipping symbolized a change of one's way of thinking and feeling about life in general and people in particular." ${ }^{28}$ Paulus berkata baptisan adalah bersekutu atau masuk ke dalam Kristus. Artinya, dengan baptisan maka juga ikut merasakan kematian Kristus. ${ }^{29}$ Sehingga zaman baru yang berisikan kebenaran, keadilan, persamaan hak dan kewajiban, kebebasan, dan karenanya syalom yang universal, kini sedang merekah dan akan segera berdiri sekali untuk selamanya sewaktu Yesus datang kembali untuk mendirikan kerajaan-Nya.

Gruchy berdasarkan pandangan Wayne E. Meeks menegaskan 2 hal, yakni: 1) bahwa kata ekklēsia, bukan synagōgē dipilih oleh kekristenan mula-mula untuk melukiskan persekutuan umat Allah, terutama karena ekklèsia merupakan terjemahan

\footnotetext{
${ }^{24}$ Yoder, The Politics of Jesus, 5-6.

${ }^{25}$ Richard A. Horsley, Jesus and Empire: The Kingdom of God and The New World Disorder (Minneapolis: Fortress Press, 2003), 79.

${ }^{26}$ Grucy, Christianity and Democracy, 48-49.

${ }^{27}$ Reinhold Niebuhr, The Nature and Destiny of Man (Westminster: Jhon Knox Press, 1996), xiii.

${ }^{28}$ Bruce J. Malina, The Social World of Jesus and The Gospels (London, New York: Routledge, 1996), 11.

${ }^{29}$ James D.G. Dunn, The Theology of Paul The Apostle (Grand Rapids: Eerdmans, 1998), 448.
} 
LXX yang lebih disukai atas kata qāhāl dalam bahasa Ibrani. ${ }^{30}$ Kata ekklessia juga membedakan orang-orang Kristen mula-mula dengan kelompok sukarela dan perkumpulan pribadi/tersendiri yang banyak jumlahnya, yang juga hidup di dunia Yunani serta yang hanya memperbolehkan orang dari status yang sama menjadi anggotanya. ${ }^{31}$ Gereja, di pihak lain, tidak memandang dirinya selaku masyarakat sukarela atau perkumpulan pribadi, tetapi sebagai suatu komunitas universal yang terwujud dalam jemaat-jemaat lokal, yang merangkum orang yang berasal dari semua kalangan masyarakat. Cara yang ditempuh oleh ekklēsia Kristen yang majemuk di berbagai daerah untuk mengorganisasikan dirinya pada mulanya bervariasi. Sekurangkurangnya di beberapa daerah, pemimpin-pemimpin setempat baik laki-laki maupun perempuan dipilih secara demokratis, misalnya dalam Kisah Para Rasul 6. Demikian juga, persoalan-persoalan utama yang dihadapi gereja yang sedang bertumbuh itu diselesaikan dalam musyawarah dan sering kali melalui konsensus (kesepakatan) misalnya dalam Kis 15 ; 2) bahwa pemakaian ekklessia dalam bahasa Yunani lebih merupakan istilah politis ketimbang kultis yang melukiskan persekutuan warga yang berkumpul untuk melaksanakan tanggung jawab kewarganegaraan mereka. Pada umumnya orang Yunani bingung karena cara orang Kristen memakai kata itu dalam teologi. Sementara bagi orang Kristen Yunani, kata itu menyiratkan analogi dengan dewan sekuler yang terdiri dari para warga dengan implikasi bahwa orang-orang Kristen bertanggung jawab untuk menjamin agar bukan hanya komunitas mereka, melainkan juga masyarakat yang lebih luas, diperintah dengan baik (bnd. 1 Kor. 6:2). ${ }^{32}$

Lebih lanjut Maan mengatakan bahwa relasi antara ekklèsia kristiani dan masyarakat politik menjadi persoalan yang mendapat perhatian utama dari para penguasa kekaisaran ketika kekristenan berkembang di seluruh Kekaisaran Romawi. ${ }^{33}$ Kekristenan semakin dianggap sebagai insititusi sosio-politik tandingan, pusat kekuasaan lain, yang membuat klaim-klaim absolut dan universal atas nama Allah. Jadi, keberadaannya sendiri memang mengganggu secara politis dan kadangkala juga secara ekonomis. Hal ini kemudian disadari oleh kekaisaran, pada waktu orang Kristen menolak untuk mengakui ilah-ilah warga lokal dan juga menolak menyembah kaisar sebagai ilahi. Pembangkangan sipil semacam itu menyuntikkan suatu dualisme kritis ke dalam masyarakat politik dan mejadi tonggak penting dalam perkembangan gagasan civil society di kemudian hari. ${ }^{34}$ Tidak mengherankan, perlu banyak upaya dari para apologet untuk meyakinkan para penguasa bahwa orang Kristen dapat menjadi orang beriman yang taat sekaligus warga negara yang baik.Orang Kristen kemudian dapat

\footnotetext{
${ }^{30}$ Grucy, Christianity and Democracy, 48-49; Pelita Hati Surbakti, “Gereja, Anak dan Bapa dalam Injil Matius: Sebuah Studi Relasional.” Jurnal Lensa, 5 (1): 54.

${ }^{31}$ Grucy, Christianity and Democracy, 50.

${ }^{32}$ Ibid., 51.

${ }^{33}$ Michael Maan, The Sources of Social Power (Cambridge: Cambridge University Press, 1986), 325.

${ }^{34}$ Grucy, Christianity and Democracy, 51-52.
} 
belajar cepat dalam lingkungan masyarakat Romawi, bahkan belajar memandang tatanan sosialnya sebagai ketetapan ilahi. ${ }^{35}$

Dari bagian ini dapat dilihat bahwa orang Kristen mula-mula berupaya keras untuk membuat suatu komunitas yang lebih baik. Hal itu dikarenakan tatanan kehidupan saat itu tidak sesuai dengan tatanan kehidupan yang diperjuangkan oleh Yesus yang telah mati di salib.

\section{Implementasi Pemikiran John W. De Gruchy}

Kehidupan sosial dalam konteks demokrasi penting dipikirkan dengan amat matang, arif, dan bijaksana agar dapat terwujud nyata dalam kehidupan dan terpelihara bagi generasi terkhusus Indonesia mendatang. Ranah hidup berdemokrasi tidak hanya sebatas tentang politik dan kekuasan, tetapi juga tentang bagaimana menjadi pelopor untuk menegakkan keadilan/kebenaran di tengah-tengah ketidakberdayaan dan kekalutan. Maka sebagai warga gereja, kita diharapkan untuk tidak menarik diri dan menafikan peran nyata untuk ikut berpartisipasi dalam emansipasi dan pengentasan persoalan dan pergumulan - bangsa yang telah mencapai taraf kompleks dan akut, bahkan dalam ranah etis-moralistis yang sekarang ini sedang krisis. Namun sebelum melihat implementasi pemikiran dari John W. De Gruchy, penulis melihat bahwa penting untuk menegaskan terlebih dahulu bagaimana posisi/kedudukan umat Kristen dalam masyarakat Indonesia yang majemuk.

Andreas A. Yewangoe dalam Tidak Ada Penumpang Gelap akan sangat menolong pembaca. Ia mengatakan bahwa umat Kristen Indonesia merupakan bagian integral bangsa. Alasannya, karena pada dasarnya umat Kristen tidak dapat dilepaskan dari bangsa Indonesia yang majemuk. ${ }^{36}$ Kemajemukan menjadi kata kunci yang patut dipertimbangkan dengan sebaik mungkin ketika bangsa ini akan didirikan oleh para founding fathers. Dengan mengakui kemajemukan, itu sama halnya dengan mengayomi atau mengajak suku, etnis, bahasa, dan agama yang heterogen - meskipun secara kuantitas berbeda - untuk menyebut diri sebagai satu identitasi bangsa, yakni Indonesia. ${ }^{37}$ Ia juga mengatakan bahwa pernyataan ini mesti terus-menerus digaungkan dan diorasikan karena tidak jarang timbul yang namanya keragu-raguan, baik di kalangan umat agama lain yang melihat umat Kristen sebagai "penumpang gelap dalam kereta yang bernama Indonesia" maupun di kalangan umat Kristen sendiri yang mengidap penyakit minderwaardigheidscompleks (rasa rendah diri) karena merasa diri minoritas. $^{38}$

Selanjutnya, tentang bagaimana mengimplementasikan - syalom dan keadilan, "teori Kerajaan Allah" dan ekklesiā Kristen yang telah dijelaskan sebelumnya - dalam konteks Indonesia sebagai negara demokrasi. Beberapa poin penting, yaitu:

\footnotetext{
${ }^{35}$ W.H.C. Frend, The Rise of Christianity (Philadelphia: Fortress Press, 1984), 131.

${ }^{36}$ Yewangoe, Tidak Ada Penumpang Gelap, 7.

${ }^{37}$ Ibid., 8-9.

${ }^{38}$ Ibid., 7.
} 


\section{Syalom dan Keadilan}

Seperti yang telah ditegaskan oleh Gruchy bahwa syalom dan keadilan adalah hal yang perlu dilakukan secara berbarengan. Bagaimana mungkin mengikrarkan syalom namun mempraktikkan ketidakadilan. Sebaliknya, keadilan niscaya akan terwujud apabila tidak mengalami penyembuhan, pemulihan, dan keutuhan hubungan secara pribadi baik dengan Tuhan maupun dengan manusia lainnya alias syalom. Dalam konteks kehidupan sosial dalam demokrasi khususnya Indonesia, keadilan merupakan nilai yang tidak bisa ditepis, diabaikan, dan dipermainkan. Berdasarkan pemikiran Gruchy, di sini warga gereja diajak untuk mengadopsi bagaimana kepedulian Tuhan kepada orang-orang yang mengalami ketidakadilan, seperti orang miskin, tertindas, janda, yatim piatu, dan masyarakat lainnya yang menjadi korban. Armand Barus melalui gagasan Reinhold Neibuhr berkata, berbicara keadilan maka tidak dapat dilepaskan dari kasih. Kasih dan keadilan bersifat dialektis. Kasih membutuhkan keadilan, dan sebaliknya keadilan merupakan implementasi dari kasih dalam masyarakat. Keadilan adalah aplikasi dari kasih. Keadilan adalah pelayanan kasih. ${ }^{39}$ Barus juga berkata, gereja adalah umat Allah. Gereja dipanggil dari dalam dunia dan dikhususkan oleh dan bagi Allah, kemudian diutus Allah ke dalam dunia. ${ }^{40}$ Sejalan dengan itu, Leonard Hale berkata, bahwa karya pelayanan gereja harus senapas dan searah dengan karya pelayanan Kristus, termasuk di dalamnya perjuangan menegakkan keadilan. ${ }^{41}$ Dalam ilmu Filsafat Manusia, makna keadilan selalu terkait dengan orang lain, yang berarti bahwa sikap adil menyangkut tentang perlakuan kita terhadap orang lain. $^{42}$ Benang merah yang dapat dilihat di sini ialah, bahwa gereja tidak dipanggil dan dieksklusifkan oleh Tuhan dari hegemoni permasalahan masyarakat, melainkan diutus ke dalam dunia untuk berkarya sebagaimana Tuhan peduli bahkan penuh kasih kepada manusia, bahkan ketika datang ke dalam dunia dalam inkarnasi Kristus. Karya Kristus bukanlah karya yang memperjuangkan permasalahan-Nya sendiri, namun perjuangan bagi orang lain. Justru karena "merekalah/kitalah” Kristus datang ke dunia.

\section{Menghadirkan Kerajaan Allah}

Perlu dan penting disadari, bahwa upaya untuk menghadirkan kerajaan Allah bukanlah upaya yang sebentar, instan dan gampang. Terlebih di Tanah Air, "rumah" dengan berbagai macam latar belakang pribadi, komunitas, dan golongan. Tidak tertutup kemungkinan munculnya gesekan-gesekan mulai dari skala kecil hingga besar. Lantas, bagaimana umat Kristen Indonesia dapat menghadirkan kerajaan Allah? Ruck dkk mengatakan bahwa umat Kristen seyogianya menjadi "komunitas yang relevan". 43 Komunitas yang relevan artinya komunitas yang memiliki pesan yang layak diterapkan

\footnotetext{
${ }^{39}$ Armand Barus, "Solidaritas Sosial Gereja”, 18.

${ }^{40}$ Ibid.

${ }^{41}$ Leonard Hale, Diutus ke dalam Dunia (Jakarta: BPK Gunung Mulia, 2016), 1.

${ }^{42}$ Kasdin Sihotang, Filsafat Manusia: Jendela menyingkap Humanisme (Yogyakarta: Kanisius, 2018), 130.

${ }^{43}$ John Ruck dan Anne Ruck, Jemaat Misioner (Jakarta: YKBK, 2011), 269-306.
} 
dan sesuai dengan konteks dari penerima pesan tersebut. Pesan umat Kristen tentu saja berdasar kepada kebenaran Allah, kebenaran Alkitab, keselamatan melalui Yesus Kristus, dan adanya kehadiran Roh Kudus. Pesan ini merupakan pegangan yang perlu digenggam erat oleh setiap umat Kristen Indonesia untuk menjadi individu dan komunitas yang relevan. Relevan tidak hanya bagi anggotanya tetapi juga bagi masyarakat sekitarnya. PGI pernah merumuskan bahwa gereja mempunyai tanggung jawab politik dalam arti aktif dan ikut serta dalam mengupayakan kehidupan berbangsa, bernegara, dan bermasyarakat berdasarkan Pancasila dan UUD 1945 dengan memperjuangkan keseimbangan antara power, justice, and love. ${ }^{44}$ Sidang Raya ke-10 DGD (Dewan Gereja-gereja Sedunia) di Busan 2013, membahas tentang gereja (umat Kristen) mengambil peran untuk menegaskan bahwa Injil memberitakan bagaimana Yesus berpihak kepada kaum miskin, tertindas dan kaum tersingkir, bukan sebaliknya. Gereja mesti bersuara protes terhadap penindasan, ketidakadilan, kemiskinan, keserakahan, dan pada gilirannya memberitakan bagaimana Allah bertindak dan berpihak kepada kaum yang menderita. ${ }^{45}$ Dari penjelasan di atas, dapat dilihat bahwa umat Kristen Indonesia, dihimbau untuk mengambil peran active not passive sebagai warga negara untuk bisa menghadirkan kerajaan Allah dalam kehidupan bergereja, bermasyarakat, dan berbangsa.

\section{Ekklesiā Kristen}

Berdasarkan kajian terhadap ekklesiā Kristen dalam pemikiran Gruchy, maka peran warga gereja yang diharapkan adalah 1) dapat menjadi ekklesiā yang mampu menegaskan persekutuan umat Allah. Persekutuan yang dimaksudkan adalah persekutuan yang welcome kepada semua orang tanpa memandang statusnya. Persekutuan ini justru mengusung baptisan sebagai penolakan radikal terhadap pembedaan-pembedaan strata sosial yang berpotensi terjadinya perpecahan. Selain itu baptisan juga dimaksudkan sebagai tanda masuknya seseorang ke dalam kelompok mesianis dalam arti kemanusiaan baru dari Allah. Dapat dikatakan baptisan merupakan tanda "penyambutan" seseorang ketika ia telah memutuskan untuk bergabung, ketimbang sebagai prasyarat untuk akan bergabung.

Selain itu, 2) diharapkan hadir menjadi komunitas yang mampu memperbaiki keadaan yang meliputi tatanan sosial-politis-ekonomis bahkan dalam ranah etismoralistis yang sekarang ini sedang mengalami degradasi. Sumadikarya ${ }^{46}$ dalam sambutannya, mengatakan bahwa warga gereja - umat Kristen - perlu memikirkan dan bertindak dengan serius bukan saja tentang dampak dari gejala-gejala kebusukan dunia, tetapi juga penyebabnya. Sumadikarya menegaskan bahwa umat Kristen penting untuk menghayati arti dari menjadi Garam dan Terang. Garam bukan hanya penyedap rasa, tetapi juga pencegah kebusukan. Terang bukan hanya sebagai penerang, tetapi juga

\footnotetext{
${ }^{44}$ Yewangoe, Tidak Ada Penumpang Gelap, 223.

${ }^{45}$ Rogate R. Mshana dan Athena Peralta (ed), Mengaitkan kemiskinan, Kesejahteraan, dan Ekologi (Jakarta: Pokja Oikotree, 2016), viii.

${ }^{46}$ Mshana dan Peralta, Mengaitkan kemiskinan, Kesejahteraan, dan Ekologi, vii.
} 
untuk mengusir kegelapan. Sabar Subekti dalam konteks merespons perkembangan kasus-kasus politik identitas dan pertumbuhan kaum fundamentalis di Indonesia ketika politik identitas dijadikan sarana untuk meraih kekuasaan, maka salah satunya agama dijadikan sebagai penggerak massa dan mengelolanya menjadi suara politik berkata bahwa gereja dan warga gereja sudah saatnya berperan aktif dalam mewujudkan perdamaian di dunia sebagaimana amanat Kepala Gereja dan sekaligus sebagai tanggung jawab sebagai warga negara. ${ }^{47}$ Dua pendapat di atas kiranya semakin meneguhkan peran warga gereja dalam kehidupan sosial khususnya dalam bangsa Indonesia yang demokratis. Ekklesiā peduli Indonesia.

\section{Kesimpulan}

Berdasarkan hasil pembahasan di atas, maka kita telah menemukan jawaban dari pokok pembahasan dalam tulisan ini yakni tentang bagaimana warga gereja bisa ikut berpartisipasi dan berkontribusi dalam kehidupan masyarakat dan bangsa yang demokrasi. Menurut pemikiran John W. De Gruchy, untuk warga gereja dapat ikut berperan aktif, maka haruslah kehadiran warga gereja berlandaskan kepada "visi profetis". Visi profetis tersebut meliputi tentang penegakan keadilan dengan syalom dan kasih, mewujudnyatakan/menghadirkan kasih Yesus dan implementasi Kerajaan Allah, dan supaya menjadi komunitas ekklesiā yang tidak membuat pembedaan-pembedaan strata kehidupan. Visi profetis ini penting sekali dijadikan sebagai dasar/landasan agar kehadiran warga gereja - umat Kristen - di tengah-tengah gegap gempita permasalahan, pergumulan bahkan primordialisme dalam kebangsaan merupakan kehadiran yang memiliki impact positif dan konstruktif. Pula, tidak tertutup kemungkinan menjadi pelopor bagi kolaborasi dengan masyarakat lintas agama dan budaya demi mewujudkan keadilan dan perdamaian di Indonesia.

\section{Referensi}

Bammel, Ernst dan Moule, C.F.D (ed). 1984. Jesus and The Politics of His Day. Cambridge: Cambridge University Press.

Barus, Armand. 2009. "Solidaritas Sosial Gereja." Jurnal Lensa, 3 (3): 1-21.

Blomberg, Craig L. 1990. Interpreting The Parables. Downers Grove, Illinois: InterVarsity Press.

Browning, W.R.F. 2014. Kamus Alkitab: Panduan Dasar ke dalam Kitab-kitab, Tema, Tempat, Tokoh, dan Istilah Alkitabiah. Jakarta: BPK Gunung Mulia.

Dunn, James D.G. 1998. The Theology of Paul The Apostle. Grand Rapids: Eerdmans.

Frend, W.H.C. 1984. The Rise of Christianity. Philadelphia: Fortress Press.

Frost, Michael dan Hirsch, Alan. 2003. The Shaping of Things to Come: Innovation and Mission forThe $21^{\text {st }}$ Century Church. Peabody: Hendrickson

Gruchy, Jhon W. De. 1995. Christianity and Democracy. Cambridge: Cambridge University Press.

Gunawan, Chandra. 2014. "Gereja Mula-mula dan Pergumulan Politik Zamannya, Serta Implikasi Bagi Pergumulan Gereja Masa Kini.” Jurnal Te Deum, 3 (2): 183-215.

\footnotetext{
${ }^{47}$ Subekti, Gereja di Tengah Maraknya Politik Identitas dan Fundamentalisme di Indonesia, 30.
} 
Hardiman, F. Budi. 2018. Demokrasi dan Sentimentalitas: Dari "Bangsa Setan-setan, Radikalisme Agama, sampai Post-Sekularisme. Yogyakarta: Kanisius, 2018.

Hauerwas, Stanley. 1981. A Community of Character: Toward a Constructive Christian Social Ethic. Notre Dame, Indiana: University of Notre Dame Press.

Held, David. 2006. Models of Democracy. Cambridge: Polity Press.

Horsley, Richard A. 2003. Jesus and Empire: The Kingdom of God and The New World Disorder. Minneapolis: Fortress Press.

Horsley, Richard A. 2014. Jesus and The Politics of Roman Palestine. Columbia: The University of South Carolina Press.

Ismail, Andar. 2019. Selamat Mengindonesia: 33 Renungan tentang Kebinekaan. Jakarta: BPKGunung Mulia.

Johnstone, Patrick. 1998. The Church is Bigger than you Think. Gerards Cross: WEC.

Kusumohamidjojo, B. 2000. Kebhinekaan Masyarakat Indonesia: Suatu Problematik Filsafat Kebudayan. Jakarta: Grasindo.

Maan, Michael. 1986. The Sources of Social Power. Cambridge: Cambridge University Press.

Malina, Bruce J. 1996. The Social World of Jesus and The Gospels. London, New York: Routledge.

Marshal, I. Howard. 2004. New Testament Theology: Many Witnesses, one Gospel. Downers Grove: InterVarsity Press.

Minear, Paul S. 2004. Images of the Church in the New Testament. Louisville: Westminster John Knox Press.

Mshana, Rogate R dan Peralta, Athena (ed). 2016. Mengaitkan Kemiskinan, Kesejahteraan, dan Ekologi. Jakarta: Pokja Oikotree.

Niebuhr, Reinhold. 1996. The Nature and Destiny of Man. Westminster: Jhon Knox Press.

Nugroho, Heru. 2012. "Demokrasi dan Demokratisasi: Sebuah Kerangka Konseptual Untuk Memahami Dinamika Sosial-Politik di Indonesia," Jurnal Pemikiran Sosiologi Volume 1 (1): 1-15.

Ruck, John dan Ruck, Anne. 2011. Jemaat Misioner. Jakarta: YKBK.

Schreiner, Thomas R. 2008. New Testament Theology: Magnifying God in Christ. Grand Rapids: Baker Academic.

Sihotang, Kasdin. 2018. Filsafat Manusia: Jendela menyingkap Humanisme. Yogyakarta: Kanisius.

Silaen, Victor. 2012. Bertahan di Bumi Pancasila: Belajar dari Kasus GKI Yasmin. Jakarta:YKBK.

Subekti, Sabar. 2013. "Gereja di Tengah Maraknya Politik Identitas dan Fundamentalisme di Indonesia." Jurnal Lensa, 5 (1): 23-33.

Surbakti, Pelita Hati. 2013. "Gereja, Anak dan Bapa dalam Injil Matius: Sebuah Studi Relasional." Jurnal Lensa, 5 (1): 49-57.

Surbakti, Pelita Hati. 2014. "Kerajaan Allah: Antara Frasa yang Relevan dan Pemaknaan yang Relevan.” Jurnal Teologi Reformed Indonesia, 4 (1): 29-42.

Yewangoe, Andreas A. 2015. Tidak Ada Penumpang Gelap: Warga Gereja, Warga Negara.Jakarta: BPK Gunung Mulia.

Yoder, Jhon H. 1972. The Politics of Jesus. Grand Rapids: Eerdmans 